\section{Metodologia de pesquisa em sambaquis: uma leitura sobre abordagens estratégicas}

\author{
Por Rafael Guedes Milheira \\ Universidade Federal de Pelotas \\ (milheirarafael@gmail.com)
}

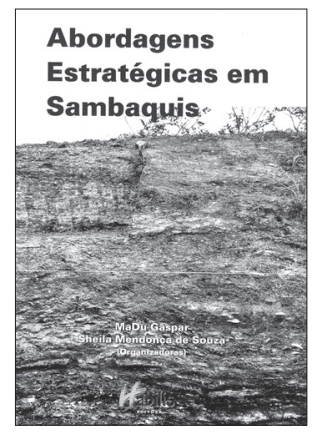

GASPAR, Maria Dulce; SOUZA, Sheila Mendonça de (Orgs.). Abordagens estratégicas em sambaquis. Erechim: Habilis Editora, 2013. 311 p. il. ISBN 978-8560967-53-7

Quando me deparei na livraria com esta obra, intitulada "Abordagens estratégicas em sambaquis", eu já sabia que o conteúdo traria grandes contribuições metodológicas para a área de Arqueologia no Brasil. É o tipo de trabalho que eu costumo chamar de "Arqueologia na veia", pois trata de temas específicos da Arqueologia (no caso, técnicas de campo), de maneira ortodoxa e interdisciplinar, contribuindo na direção de como e por que fazer trabalhos de campo, otimizando recursos e maximizando resultados. Ao iniciar as primeiras páginas, foi ficando evidente que o livro, embora tenha um foco centrado na temática dos sítios sambaquieiros da costa litorânea brasileira, dialoga e propõe técnicas de campo que podem ser facilmente utilizadas em todos os sítios arqueológicos pré-históricos (e não seria exagero incluir os sítios históricos) do Brasil. Aliás, essa foi também a impressão de André Prous na apresentação do livro, ao comentar que "o presente livro será, sem dúvida, de grande utilidade para os estudantes e pesquisadores não apenas para aqueles que estudam os sambaquis, mas também para todos os praticantes de Arqueologia".

Na introdução, as organizadoras recorrem a um breve histórico das pesquisas em sambaquis no Brasil desde o século XIX, os avanços e desafios dos últimos anos, sobretudo com o acúmulo de conhecimento resultante de grandes projetos temáticos financiados, predominantemente, por agências nacionais e públicas de pesquisa, amplamente divulgados no cenário nacional e internacional. Esses projetos foram a base das experiências dos autores dos treze capítulos do livro, e é claro que as discussões amadurecidas só chegaram ao alto nível de qualidade por conta da formação de equipes interdisciplinares, experientes e altamente comprometidas com o estudo dos sambaquis da costa brasileira. $\bigcirc$ livro, além do formato impresso, é acompanhado (opcionalmente) por um CD-ROM, que é o "Guia ilustrado das abordagens estratégicas em sambaquis". Esse guia é um banco de imagens devidamente legendadas, que exemplificam as orientações metodológicas apresentadas nos textos, tornando a leitura da obra mais didática e acessível.

Seria demasiadamente enfadonho sintetizar aqui o conteúdo e as discussões de cada um dos capítulos do livro. Porém, arrisco-me a classificar os temas dos textos em três tópicos latu sensu: prospecção e registro de imagens em campo; estudos e coleta para sedimentologia e geoarqueologia; análises e coleta de material bioarqueológico (zooarqueologia, arqueobotânica e antropologia física). Embora haja uma divisão de temáticas abordadas no livro, há algumas questões que permeiam todos os textos e que merecem ser destacadas, por exemplo: como coletar amostras em campo, para que coletá-las e como registrálas e acondicioná-las devidamente para análises futuras em laboratório. São questões relevantes e que atormentam (pelo menos, deveriam atormentar) qualquer coordenador de campo, na medida em que nos fazem pensar sobre a fragilidade e sutileza do registro arqueológico, a facilidade em confundir, misturar e perder amostras e, portanto, dados arqueológicos. E, por fim, refletir sobre o tamanho adequado das amostras versus o tamanho, geralmente limitado, das nossas reservas técnicas espalhadas pelo Brasil.

Eis uma das principais contribuições do livro: os autores conseguem, com maestria, demonstrar que é possível realizar intervenções pontuais nos sítios arqueológicos, minimizando os impactos físicos aos pacotes 
deposicionais e maximizando os resultados interpretativos. Essa conta positiva é possível com a padronização adequada e experimentada de coletas amostrais, que permitem obter vestígios microscópicos oriundos desses sítios arqueológicos monumentais, materiais que, embora sejam micro em tamanho, ao serem identificados, permitem avançar em discussões de larga escala, que vão da economia e dieta alimentar até práticas de manejo da paisagem e conformação territorial; vide o caso dos parasitos, o estudo da fauna ictiológica e o estudo dos carvões que compõem as fogueiras rituais e de aquecimento residencial.

A padronização das amostras em volume, formato e registro são temas importantes e que foram amplamente discutidos no livro por quase todos os autores. Da mesma forma, os autores foram bastante contundentes ao incentivar o uso de protocolos de coleta altamente padronizados, que permitam a comparação das amostras no processo laboratorial. Porém, há um aspecto que me preocupou na leitura e que poderia ter sido mais bem conduzido, talvez, até mesmo, por um capítulo à parte: o perigo da 'superpadronização'. Os autores demonstraram uma grande preocupação em tecer uma escrita que, não obstante tenha um caráter bastante técnico, consiga atingir os recéminiciados em Arqueologia. É até curioso um texto acadêmico que ensina como segurar a pá, para que lado e em que sentido se deve realizar uma limpeza e retificação de perfil, e de que forma se deve preencher um diário de campo.

Com certeza, os autores estiveram preocupados em manter uma linguagem bastante clara e acessível, visto que, no cenário nacional universitário, novos cursos de graduação em Arqueologia vêm sendo criados sistematicamente, o que gera novos leitores. Eu, como professor de práticas de campo e laboratório, fico extremamente agradecido, pois vale lembrar que, nas graduações brasileiras, utilizar um texto em língua estrangeira é quase um atentado, portanto textos que 'traduzam', por assim dizer, técnicas e métodos difundidos internacionalmente são muito bem-vindos. Entretanto, retomando minha preocupação com a 'superpadronização', fiquei pensando que um jovem leitor poderá facilmente entender que as escavações arqueológicas devem atingir um alto nível de padronização, em que todas as informações devem ser protocoladas em fichas de conteúdo fechado e limitadas em seus campos de respostas, uma espécie de 'ficha de ticar', em que caberia ao arqueólogo coletar amostras em volumes prédeterminados, preencher os protocolos e armazená-las adequadamente para incorrer corretamente às análises laboratoriais. Certamente, não foi essa a mensagem que moveu o interesse dos autores ao compor a obra, contudo vale a pena lembrar os leitores de que fazer ciência requer um alto grau de sensibilidade e subjetividade e que, não seria incorreto dizer, em Arqueologia, pelo caráter empírico, confiar no feeling não é ceder à falta de objetividade.

Trago essa discussão exatamente pela minha experiência como professor de graduação e pós-graduação em Arqueologia, e por estar imerso num cenário em que essa disciplina é cada vez mais demandada pelos empreendimentos de engenharia no Brasil, por conta das práticas de licenciamento ambiental. No contexto das atividades de licenciamento, vem se tornando senso comum que a qualidade das pesquisas arqueológicas está relacionada ao volume de dados que gera e, sobretudo, à confiabilidade técnica que conformou os dados. Nesse sentido, a padronização das informações registradas em campo vem sendo tomada como essencial, refletindo qualidade e confiabilidade na pesquisa. Logo, o estabelecimento de um protocolo de coleta, em todas as etapas do quotidiano da pesquisa, permite aos arqueólogos gerarem dados 'a toque de caixa', com baixo índice de subjetividade científica e que nega ou dificulta o exercício da reflexão. Nesse sentido, é importante ressaltar que - livro em tela contribui para a divulgação de técnicas padronizadas, que devem ser adotadas nas diferentes pesquisas após reflexões aprofundadas, algo que, muitas vezes, a Arqueologia de contrato não atende.

Há, ainda, outro aspecto a destacar. A coleta e o estudo cuidadoso das coleções artefatuais e das amostras biológicas em campo elucidam uma discussão emergente

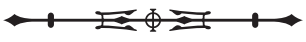


no Brasil. Cada vez mais, arqueólogos têm se debruçado sobre uma tendência recente em desvalorizar, de certa forma, atividades interventivas nos sítios arqueológicos, baseando-se no discurso do preservacionismo e da limitação das reservas técnicas. Da mesma forma, desconsideram a importância de análises sobre coleções fragmentárias, argumentando que somente as coleções artefatuais mais significativas deveriam ser abordadas, pelo seu cunho elucidativo, simbólico e educativo. Porém, com a leitura da obra, fica também evidente que foi somente com novas intervenções arqueológicas em sítios já bastante estudados, e com base em análises de coleções até então desconsideradas pelo seu aspecto microescalar ou secundário, que novos modelos teóricos sobre as sociedades sambaquieiras puderam ser constituídos, ou seja, esses modelos são fruto de trabalhos de campo exaustivos, experimentação, discussões amadurecidas e publicação de dados. Invariavelmente, essas novas intervenções arqueológicas avolumaram as reservas técnicas, o que leva a discussão para além da Arqueologia tradicionalmente realizada no Brasil, invadindo temas como gestão do patrimônio arqueológico, reservas técnicas, ciência da conservação e museologia.

$\mathrm{Na}$ busca da popularização de uma abordagem estratégica bem pensada, que dialogue com pesquisas nacionais e internacionais, a obra contribui amplamente para o desenho de projetos de pesquisa e, com certeza, se tornará uma boa referência. Considerando o pool de pesquisadores que contribuíram para a tessitura do livro, e pelo seu conhecimento de técnicas importantes que ultrapassam as práticas de campo, fico na expectativa da publicação de um segundo volume, composto por abordagens metodológicas em laboratório, envolvendo as mesmas temáticas já abordadas na obra. 
